\title{
Negative Spillover Effect on Demand for US Pork and Vegetables Caused by BSE Outbreak
}

\author{
Takashi Ishida \\ Graduate School of Horticulture, Chiba University \\ 648, Matsudo Matsudo, Chiba, Japan \\ Tel: 81-47-308-8932Ｅ-mail: t.ishida@chiba-u.jp \\ Noriko Ishikawa \\ Faculty of Economics, Konan University \\ 8-9-1, Okamoto, Higashi-Nada-ku \\ Kobe, Hyogo, 685-8501, Japan
}

Tel: 81-78-431-4341ex. 5029 E-mail: ishikawa@center.konan-u.ac.jp

Mototsugu Fukushige (Corresponding author)

Garaduate School of Economics, Osaka University

1-7, Machikaneyama-cho, Toyonaka, Osaka, Japan

Tel: 81-6-6850-5248Ｅ-mail:mfuku@econ.osaka-u.ac.jp

Received: February 24, $2012 \quad$ Accepted: March 14, $2012 \quad$ Published: May 1, 2012

doi:10.5539/jfr.v1n2p32

URL: http://dx.doi.org/10.5539/jfr.v1n2p32

The authors wish to acknowledge financial support from the Urakami Foundation

\begin{abstract}
After the BSE outbreak in December 2003 in the United States, Japanese consumers refrained from buying US beef and other agricultural products produced in the US. We use a probit model to analyze how the BSE outbreak has affected demand for products other than beef and what household characteristics have an impact on decisions to purchase US agricultural products. We show that the BSE outbreak has had a significant impact on the purchasing decisions of Japanese consumers. Presence of children in the household and interest in country-of-origin information also significantly affected consumer attitudes and their purchases of US agricultural products.
\end{abstract}

Keywords: BSE, Probit model, Purchase decisions

\section{Introduction}

Consumers cannot fully assess the safety of agricultural products directly. Hence, consumers must rely upon other factors such as national image to evaluate the quality of products from a country (van der Lans et al., 2001; Beverland \& Lindgreen 2002; van Ittersum et al., 2003x). They use this image as stereotypical information (Janda \& Rao, 1997; Maheswaran, 1994; Hong \& Wyer, 1989, 1990). Once a country's image is damaged by a food safety crisis, consumers may gain an impression of health risks from stereotypical information and change their purchasing behavior. That is, the crisis creates concerns of negative spillover effects to totally unrelated agricultural products from the same country. In fact, the outbreak of bovine spongiform encephalopathy (BSE) in December 2003 in the United States (US), led some Japanese consumers to refrain from buying not only US beef but also other agricultural products from the US. Such negative spillover effects result in economic losses to producers and distributors of agricultural products. Therefore, it is important to understand the negative spillover effect of the food safety crisis on other agricultural products from the same country. 
Various studies have analyzed the impact of agricultural product safety crises on demand for related products. Verbeke and Ward (2001), Gould and Villarreal (2002), Marsh et al. (2004), Peterson and Chen (2005) and Saghaian et al. (2007) analyze the impacts of the BSE outbreak on demand for beef and on other meats that are substitutes for beef. Nevertheless, they do not focus on negative spillover effects on other agricultural products.

How then does the level of negative spillover effect vary according to household? Responses to a food safety crisis vary across consumers (Barrena \& Sánchez, 2010). Therefore, we can consider the possibility that the level of negative spillover effect also varies across types of households. While this has an important implication for risk communication, there are no empirical research analyses of this question.

Inconsistent behavior of consumers in different types of households in the face of a product-related crisis can be explained not only by risk perception but also by risk attitude (Pennings et al., 2002). Risk perception is a consumers' assessment of the uncertainty of a risk. Risk attitude explains the extent to which consumers dislike the risk. Economic analyses of risk perception and risk attitude are based on the random utility model. In the random utility model, risk perception is a consumer's subjective view of the probability of risk (Zepeda et al., 2003). In addition, risk attitude is considered a combination of utility from consumption of products and disutility from health problems in the model. Specifically, we can identify consumers' purchase decisions regarding US agricultural products by comparing the expected utility when the product is "safe" and that when it is hazardous to health

We analyze how the negative spillover effect caused by the BSE outbreak in the US varies according to the attributes of Japanese households by means of a random utility model. We deal with this case for the following two reasons. First, Japanese consumers reacted strongly to the BSE outbreak because it is well known in Japan that BSE is a serious disease of cattle and is potentially transmissible to humans through eating infected meat. Second, it is easy to detect changes in consumer behavior before and after the BSE outbreak in Japan because many Japanese consumers had purchased US agricultural products before it.

We choose pork, which is perceived as a substitute for beef, and vegetables, which are not believed to be related directly to demand for beef to analyze the difference between the impacts of the BSE outbreak on agricultural products. Because there may be a difference between utility functions for pork and for vegetables, we consider the expected utility functions for the respective agricultural products.

We also note that the level of negative spillover effects may vary with the subjective probability of and disutility from health hazards, and utility from the US agricultural products, which depend on household characteristics. Therefore, we conducted a questionnaire survey of randomly sampled households to discover these factors. In this study, we formulate the purchase decisions for US pork and vegetables using a probit model. A summary of our results is as follows. (1) Households that buy US beef tend not to refrain from buying US pork and vegetables. (2) Households that consume less beef have a tendency not to reduce their demand for US pork and vegetables. (3) Households that care about the origin of their agricultural products tend to refrain from buying US agricultural products. (4) Households without children are apt to refrain from buying US pork compared with households with children.

This paper consists of six sections. In the second section, we give an outline of the questionnaire survey conducted in this study. We explain the model in the third section, and show the empirical results in the fourth section. In the fifth section, we estimate the probabilities of purchasing US agricultural products. In the final section, we summarize this paper and mention some remaining issues.

\section{Survey Overview}

We conducted a questionnaire survey in November 2006 to observe the impact of the BSE outbreak in the US on Japanese consumers' demand for US agricultural products. We constructed a sample of 1000 subjects from households in Osaka and Tokyo to compare consumer attitudes in these areas. In Japan, there are areas where consumers favor beef over pork and vice versa. Osaka is a notable area where residents consume more beef than pork, and in Tokyo, residents consume more pork than beef. We can see this difference by comparing expenditure on beef and pork in Figure 1. Figure 1 shows that households in Osaka purchase more beef than do households in Tokyo, and households in Tokyo purchase more pork than do households in Osaka. Consumers who prefer beef may perceive a higher probability of health hazards from beef (Renner et al., 2008). We assume that the subjective probability of suffering health hazards from US agricultural products is higher in areas where households consume more beef than pork. We chose subjects at random from the telephone directory and sent them questionnaires with gift cards worth 500 yen as a reward for cooperating in the survey.

In the questionnaire, we asked whether respondents had consumed US beef "before" the BSE outbreak occurred 
in the US and about their willingness to buy US beef "after" the event. The Japanese government banned imports of US beef until December 2005, after which all imports of US beef were again banned from January 2006. Moreover, some retail outlets in Japan hesitate to sell US beef even after the resumption of trade in July 2006. The question in our questionnaire was thus not whether the respondents had bought US beef, but whether it was acceptable for them to buy it. We asked whether they bought US beef at the time when the US had not introduced blanket testing of cows for BSE. If the answer was "no," we also asked whether they would buy US beef if blanket testing were introduced. Moreover, we asked whether respondents had consumed US pork (and US vegetables) before the BSE outbreak, and whether they had refrained from buying US pork (and US vegetables) after the event, to detect shifts in consumer attitudes before and after the BSE outbreak.

We also asked households whether they were concerned about where their agricultural products came from before the BSE outbreak. We consider that the interest of consumers in country-of-origin information was one of the most important factors influencing the demand for agricultural products. That is, consumers who are concerned about country-of-origin information may have a greater negative impact on the demand for US agricultural products because of the BSE outbreak. It is also noted that family structure and income of households affect the demand for agricultural products with potential health hazards (Lin 1995; Dosman et al., 2002). Therefore, we asked households about their family structure and income, which may affect the demand for US agricultural products. In terms of family structure, we asked whether households had any members aged under 20 or over 60 years.

We had 489 surveys returned from Tokyo and 525 from Osaka. In this study, we focus on the households that had purchased all three US agricultural products (beef, pork and vegetables) before the BSE outbreak, because it was assumed that the other households never bought US agricultural products. There were 193 respondents in Tokyo and 190 in Osaka who had purchased all three US agricultural products before the BSE outbreak.

Table 1 shows the percentages of households that did not avoid US pork and vegetables in each area (Tokyo and Osaka), and, in each case, the willingness of consumers to buy US beef with or without blanket testing. We obtain three interesting results. First, households that were willing to buy US beef (regardless of blanket testing) tended not to avoid either of the other US agricultural products compared with those who were unwilling to do so even if blanket testing were to be introduced. Second, households in Tokyo that consumed less beef tended not to avoid the other two US agricultural products compared with households in Osaka that preferred beef. Finally, some households avoided US pork rather than vegetables because of the BSE outbreak. These results indicate that the probability of avoiding US agricultural products varies according to both consumer attitudes toward US beef and frequency of households' consumption of beef. Moreover, we note that the BSE outbreak had different impacts on the demands for US pork and vegetables.

\section{Model}

In this paper, we analyze the types of households that tended to avoid US agricultural products other than beef in response to the BSE outbreak according to the results of the questionnaire survey. We also clarify the differences in the impact of BSE on these products. Viscusi (1990) analyzes behavior of consumers faced with risk using a discrete choice demand model and assumes that consumers maximize their expected utility under uncertainty. According to Viscusi (1990), we construct a consumer decision-making model for US pork and vegetables as follows.

We suppose that households decide whether to avoid an agricultural product $\left(y_{j}=0\right)$ or not $\left(y_{j}=1\right)$ in accordance with the magnitude of their expected utility. The subscript $j$ indicates US pork and vegetables and takes pork or vegetable, respectively. We assume that if consumers bought US agricultural products, they might suffer a health hazard. Let $\pi_{j}$ be the subjective probability of suffering a health hazard from the agricultural products. We also assume that consumers have a utility function $U_{j}($ safe $)$ if they do not suffer a health hazard and have $U_{j}$ (hazard) if they do. We specify that the expected utility goes to zero if households refrain from buying agricultural products. Households do not avoid US agricultural products if: 


$$
\left(1-\pi_{j}\right) U_{j}(\text { safe })+\pi_{j} U_{j}(\text { hazard })>0
$$

and otherwise they do. We can rewrite (1) as:

$$
U_{j}(\text { safe })+\pi_{j}\left(U_{j}(\text { hazard })-U_{j}(\text { safe })\right)>0 .
$$

The second term of the left-hand side, $U_{j}($ hazard $)-U_{j}($ safe $)$, indicates disutility when consumers suffer health hazards from US agricultural products.

We measure the consumer decisions to purchase US agricultural products using a probit model based on equation (2). The probit model is one of the discrete choice models that estimate the effects of explanatory variables on the binary outcomes. For example, Verbeke et al., (2000) use such a model to analyze the factors that affected consumer purchase decisions for beef after the BSE crisis.

First, let $y_{i}^{*}$ be a continuous variable that represents the latent preference of individual $i$. Based on equation

(2), we set the latent variable $y_{i}^{*}$ as:

$$
y_{j}^{*}=U_{j}(\text { safe })+\pi_{j}\left(U_{j}(\text { hazard })-U_{j}(\text { safe })\right)+u
$$

where $u$ is the error term that follows a standard normal distribution. We suppose that the observed choice $y_{i}$ is related to the latent variable $y_{i}^{*}$ in accordance with the following equation:

$$
\begin{aligned}
& y_{j}=1 \quad \text { if } \quad y_{j}{ }^{*}>0, \\
& y_{j}=0 \quad \text { if } \quad \text { otherwise. }
\end{aligned}
$$

We represent the probability Prob $\left(y_{j}=1\right)$ that households do not refrain from buying each US agricultural product after the BSE outbreak as follows:

$$
\operatorname{Prob}\left(y_{j}=1\right)=\Phi\left\lfloor U_{j}(\text { safe })+\pi_{j}\left(U_{i}(\text { hazard })-U_{j}(\text { safe })\right)+u\right\rfloor
$$

and the probability Prob $\left(y_{j}=0\right)$ that households are discouraged from buying US products is expressed by:

$$
\operatorname{Prob}\left(y_{j}=0\right)=1-\Phi\left[U_{j}(\text { safe })+\pi_{j}\left(U_{j}(\text { hazard })-U_{j}(\text { safe })\right)+u\right\rfloor
$$

where $\Phi[\bullet]$ is the cumulative distribution function of the standard normal distribution. Then the log likelihood function is denoted as:

$$
\begin{aligned}
\log L= & \sum_{y_{j}=1} \log \left[\Phi\left\{U_{j}(\text { safe })+\pi_{j}\left(U_{j}(\text { hazard })-U_{j}(\text { safe })\right)\right\}\right] \\
& +\sum_{y_{j}=0} \log \left[1-\Phi\left\{U_{j}(\text { safe })+\pi_{j}\left(U_{j}(\text { hazard })-U_{j}(\text { safe })\right)\right\}\right]
\end{aligned}
$$

Therefore, the difference in degree of negative spillover effect is explained by the difference in $\pi_{j}$, $U_{j}($ hazard $)-U_{j}($ safe $)$ and $U_{j}(s a f e)$ among households. In this model, risk perception is indicated by $\pi_{j}$ and risk attitude by $U_{j}($ hazard $)-U_{j}($ safe $)$ and $U_{j}($ safe $)$. Next, we specify these variables as follows. 
Consumers' beef purchasing behavior after the BSE outbreak may be linked to the level of damage to the national image of US agricultural products. Specifically, it may be considered that consumers who avoid US beef because of the BSE outbreak also perceive high risks in other agricultural products from the US. Therefore, we classify consumers into three categories depending on their willingness to buy US beef: (1) consumers who are willing to buy US beef at this time, when the US has not yet introduced blanket testing; (2) consumers who would be willing to buy US beef if blanket testing were introduced; and (3) consumers who would not be willing to buy it even if blanket testing were introduced. We assume that the subjective perception of the probability of a health hazard from US agricultural products, $\pi_{j}$, depends on the willingness of consumers to buy US beef after the BSE outbreak and where they live.

Area of residence may also affect the level of perceived risk. Tonsor et al. (2009) show that perceived risk of BSE differs among countries. Purchasing behavior, which includes frequency of purchase, is dependent on country or area of residence. Frequency of purchase of beef affects the ability to assess its safety (Henson and Northen, 2000). The more beef a consumer buys, the higher the probability of encountering a perceptible health hazard (Renner et al., 2008). Therefore, consumers who had purchased more US beef may have perceived greater risk, not only in US beef, but also in other US agricultural products. Thus, we distinguish between households in Tokyo, where residents tend to consume pork rather than beef, and those in Osaka where residents prefer beef. Then, we formulate $\pi_{j}$ as follows:

$$
\pi_{j}=\theta_{1 j}+\tau_{11 j} \text { beef } f_{A}+\tau_{12 j} \text { beef } f_{B}+\tau_{13 j} \text { tokyo }
$$

The variable beef $_{A}$ is a dummy variable that takes a value of one if households are willing to buy US beef, and zero otherwise. The variable beef $_{B}$ is a dummy variable that takes the value of one if households would be willing to buy US beef if blanket testing were introduced, and zero otherwise. The variable tokyo is a dummy that takes the value of one if households are in Tokyo, and zero if they are in Osaka. We also note that $\theta_{1 j}$ is a constant term and $\tau_{11 j}, \tau_{12 j}$, and $\tau_{13 j}$ are parameters.

The interest of consumers in country-of-origin information may affect the level of risk they accept. Consumers who estimate greater disutility from US agricultural products may pay more attention to the source of the agricultural products. Therefore, we specify the disutility from health hazard $U_{j}$ (hazard) $-U_{j}(s a f e)$ using variables that indicate the level of awareness of country-of-origin information. That is:

$$
U_{j}(\text { hazard })-U_{j}(\text { safe })=\theta_{2 j}+\tau_{21 j} \text { country }{ }_{j}
$$

The variable country $_{j}$ is a dummy that takes the value of one if households pay attention to country-of-origin information of agricultural products, and zero otherwise; $\theta_{2 j}$ is a constant term; and $\tau_{21 j}$ is a parameter.

Family structure and household income affect the preference for US pork and vegetables. Therefore, we classify households into two categories according to age of family members: (1) households with one or more members aged under 20 years, and (2) households with one or more members aged over 60 years. We also take the logarithm of household income and use it as an explanatory variable. Then, we formulate $U_{j}(s a f e)$ as:

$$
U_{j}(\text { safe })=\theta_{3 j}+\tau_{31 j} \text { chi }+\tau_{32 j} \text { old }+\tau_{33 j} \log (\text { inc })
$$

Where $j=$ pork, vegetable. The variable $c h i$ is a dummy variable that takes the value of one if a member of the household is under 20, and zero otherwise. The variable old is a dummy variable that takes the value of 
one if a member of the household is over 60 , and zero otherwise. The variable $\log ($ inc $)$ is the logarithm of income; $\theta_{3 j}$ is a constant term; and $\tau_{31 j}, \tau_{32 j}$, and $\tau_{33 j}$ are parameters.

Substituting equations (8), (9), and (10) into equation (3), we represent the latent variable $y_{i}^{*}$ as:

$$
\begin{aligned}
y_{j}^{*}= & \theta_{3 j}+\tau_{31 j} \text { chi }+\tau_{32 j} \text { old }+\tau_{33 j} \log (\text { inc }) \\
& +\left(\theta_{1 j}+\tau_{11 j} \text { beef }_{A}+\tau_{12 j} \text { beef }_{B}+\tau_{13 j} \text { tokyo }\right)\left(\theta_{2 j}+\tau_{21 j} \text { country }{ }_{j}\right)+u
\end{aligned}
$$

If we express $y^{*}=f(x)+u$, we can rewrite equation (7) as:

$$
\log L=\sum_{y_{j}=0} \log [1-\Phi\{f(x)\}]+\sum_{y_{j}=1} \log [\Phi\{f(x)\}]
$$

The definitions and the means of explanatory variables by area are shown in Table 2. To discuss the representativeness of the sample in terms of demographics, family structure and income, we compare the means shown in Table 2 with those of the population. The sample means of the demographic variables are as follows. The proportion of households with children under 20 years old is 0.24 in Tokyo and 0.30 in Osaka. The proportion of households with a person over 60 years old is 0.64 in Tokyo and 0.58 in Osaka. Average annual household income is 7.22 million yen in Tokyo and 6.63 million yen in Osaka. The figures for the population in each area are as follows. According to census data, the proportion of households with children under 18 years old is 0.18 in Tokyo and 0.24 in Osaka. The census also shows that the proportion of households with an elderly person over 65 years old is 0.28 in Tokyo and 0.32 in Osaka. According to a national survey of family income and expenditure, average annual household income is 7.80 million yen in Tokyo and 6.44 million yen in Osaka. We cannot make a simple comparison between the sample and the population, because in the census, children are defined as those under 18 years old and elderly people are defined as those over 65 years old. Even so, we note that sampling is biased toward households with elderly people. Therefore, we must consider how demographics affect consumer decision making below.

\section{Results}

We estimate a probit model using the maximum likelihood method. First, we set constant terms $\theta_{1 j}$ and $\theta_{2 j}$

equal to one to identify $\theta_{3 j}$. We choose a model that minimizes Akaike's information criterion (AIC) among all the combinations of the candidates for explanatory variables. The criterion is expressed as:

$$
A I C=-2 \ln (L)+2 k
$$

Where $L$ is the likelihood of the model and $k$ is the number of parameters. The empirical results of the full model, including all explanatory variables, and the minimum AIC model are reported in Table 3.

Table 3 shows that the estimated coefficient of beef $f_{A}$ is positive and statistically significant in the decision-making model for both pork and vegetables. This indicates that households that are willing to buy US beef without blanket testing tend not to avoid US pork or vegetables. We also note that the coefficient of beef ${ }_{B}$ is estimated as positive and statistically significant in the decision-making model for pork and the value is smaller than that for beef $_{A}$. The difference in magnitude of the coefficient for beef $f_{A}$ and beef $_{B}$ implies that the BSE outbreak impacted the demand, not only for US beef, but also for other agricultural products produced in the US; however, households that estimate their own level of health risk as being lower do not appear to avoid US pork.

We also note that the estimated coefficient of tokyo is positive in the decision-making model for both products and statistically significant in the model for pork. That is, households in Tokyo, where residents are less fond of beef, tend not to avoid US agricultural products compared with those in Osaka. This means that households that 
prefer beef, in other words, households that have more opportunities to consume it, may perceive a higher probability of a health hazard from US agricultural products, as Renner et al. (2008) point out.

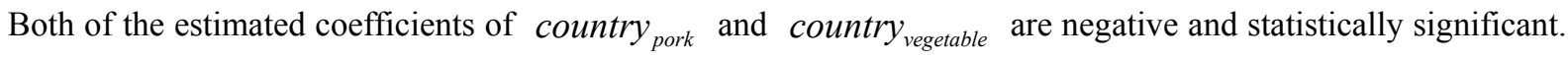

That is, households that pay more attention to country-of-origin information for agricultural products tend to avoid US agricultural products. This implies that households that are nervous about the origin of agricultural products may estimate their disutility of health hazard to be higher than that of others.

We show that the coefficient for chi is estimated as positive and statistically significant in the decision-making model for pork. In other words, households with children under 20 are less likely to avoid US pork than those without. This may be because of a difference in dietary patterns in households with or without children. That is, we consider that households with children obtain greater utility from consuming US pork compared with other households.

\section{Analysis of Purchase Probability}

In this section, we assess the probabilities of refraining from buying US agricultural products in terms of household characteristics. In this section, we describe the probabilities of avoiding products as "hesitation probabilities." To examine avoidance in more detail, we conduct the following two analyses using the results obtained in the previous section. First, to verify what characteristics of households have a significant impact on the decisions of households to purchase US agricultural products, we clarify the characteristics of households according to the results of the estimated variables in the minimum AIC model shown in Table 3 . Table 3 shows that the variables tokyo and country ${ }_{j}$ are selected in the minimum AIC decision-making model for both agricultural products. Therefore, we split the characteristics of households into two types: households living in Tokyo (i.e., the case where tokyo $=1$ ); and households in Osaka (i.e., the case where tokyo $=0$ ). Moreover, we also split the characteristics of households into two groups: households that pay attention to country-of-origin information for agricultural products (i.e., the case where country $y_{j}=1$ ); and households that do not (i.e., the case where country $\left.y_{j}=0\right)$.

In terms of a willingness to buy US beef, both beef $_{A}$ and beef $_{B}$ are selected in the decision-making model for pork, and beef $f_{A}$ is selected in the model for vegetables. To estimate the probability of buying US pork, we divide the characteristics of households into three types: (1) households willing to buy US beef without blanket testing (i.e., the case where beef $_{A}=1$ and beef $_{B}=0$ ); (2) households unwilling to buy US beef if blanket testing were introduced (i.e., the case where beef $_{A}=0$ and beef $_{B}=1$ ); and (3) households unwilling to buy US beef even if blanket testing were introduced (i.e., the case where $b e e f_{A}=0$ and beef $_{B}=0$ ). For US vegetables, we also divide the characteristics of households into two types: (1) households willing to buy at this time, when the blanket testing has not yet been introduced (i.e., the case where beef $f_{A}=1$ ); and (2) others (i.e., the case where beef $_{A}=0$ ).

The variable $c h i$, which indicates whether the household has children, is selected in the decision-making model for pork. Therefore, we estimate the probability of buying US pork according to another two household characteristics: (1) households with one or more members aged under 20 years (i.e., the case where chi=1); and (2) others (i.e., the case where $c h i=0$ ).

Thus, we estimate the probabilities of buying US pork separately for 24 types of household $(2 \times 2 \times 3 \times 2)$ and estimate probabilities of buying US vegetables separately for eight types $(2 \times 2 \times 2)$. From equation (6), the probability of avoiding US pork can be estimated by: 


$$
\begin{aligned}
& \operatorname{Prob}\left(y_{\text {pork }}=0\right) \\
& =1-\Phi\left[\hat{\theta}_{3 \text { pork }}+\hat{\tau}_{31 \text { pork }} \text { chi }+\left(1+\hat{\tau}_{11 \text { pork }} \text { beef }_{A}+\hat{\tau}_{12 \text { pork }} \text { bee } f_{B}+\hat{\tau}_{13 \text { pork }} \text { tokyo }\right)\left(1+\hat{\tau}_{21 \text { pork }} \text { country }_{\text {pork }}\right)\right]
\end{aligned}
$$

and the probability of avoiding US vegetables is estimated by:

$$
\begin{aligned}
& \operatorname{Prob}\left(y_{\text {vegetable }}=0\right) \\
& =1-\Phi\left[\hat{\theta}_{3 \text { vegetable }}+\left(1+\hat{\tau}_{21 \text { vegetable }} \text { country } \text { vegetable }\right)\left(1+\hat{\tau}_{11 \text { vegetable }} \text { beef } f_{A}+\hat{\tau}_{13 \text { vegetable }} \text { tokyo }\right)\right]
\end{aligned}
$$

where $\hat{\theta}_{3 j}, \hat{\tau}_{31 j}, \hat{\tau}_{21 j}, \hat{\tau}_{11 j}, \hat{\tau}_{12 j}$ and $\hat{\tau}_{13 j}(j=$ pork, vegetable $)$ are the estimated parameters.

Figure 2 is a bar chart that shows the probabilities of refraining from buying US pork and vegetables in each type of household. The black bar shows this probability for households willing to buy immediately without blanket testing. The gray bar shows the probability for households willing to buy US beef if blanket testing were introduced. The white bar shows the probability for households unwilling to buy US beef even with blanket testing.

The "hesitation probabilities" of households willing to buy US pork if blanket testing were introduced are around 20 to 40 points higher than those for households willing to buy US beef without blanket testing. (Compare the black and the gray bars for US pork in Figure 2.) In addition, the hesitation probabilities of households unwilling to buy even with blanket testing are 10 to 20 points higher compared with those of households willing to buy if blanket testing were introduced. (Compare the gray and the white bars of US pork in Figure 2.) In terms of probability of avoiding US vegetables, the hesitation probabilities of households willing to buy US beef without blanket testing are around 20 points higher than those of others. (Compare the black and the white bars of US vegetables in Figure 2.) Compared with the probabilities of avoiding both US pork and vegetables according to location of households, the hesitation probabilities in Osaka, where residents prefer beef, are around 5 to 10 points higher than those in Tokyo. We also show that households that pay attention to country-of-origin information have higher probabilities of avoiding US agricultural products. The hesitation probabilities are around 10 to 25 points higher for US pork, and around 20 points higher for US vegetables. Moreover, the hesitation probabilities for households without children are 5 to 15 points higher than those for households with children. These results show that the willingness of households to buy US beef and their interest in country-of-origin information have a more significant impact on households' purchase decisions of US agricultural products compared with frequency of consumption and family structure.

We next discuss the impact of willingness of households to buy US beef and their interest in country-of-origin information in more detail. To verify the differences in the impact on consumer attitudes toward US pork and US vegetables, we calculate the probabilities of avoiding each product according to the willingness of households to buy US beef and their interest in country-of-origin information. In terms of willingness of households to buy US beef, the average probability of avoiding US pork is $19 \%$ for households willing to buy US beef without blanket testing, $31 \%$ for households willing to buy US beef if blanket testing were introduced and $64 \%$ for households unwilling to buy US beef. That is, the hesitation probability of households willing to buy US beef with blanket testing is 31 points higher and that of households unwilling to buy US beef even with blanket testing is 45 points higher than that of households willing to buy US beef without blanket testing.

In terms of the interest of households in country-of-origin information, the hesitation probability for pork when households pay attention to county of origin is estimated as 53\%, which is 17 points higher than that for households who do not. The hesitation probability for US vegetables among households that pay attention to country-of-origin information is estimated as $33 \%$, which is 21 points higher than that for households that do not.

We conclude that both households' purchase attitudes toward US beef and the interest of households in country-of-origin information have a significant impact on the purchasing decisions of households regarding US agricultural products. In addition, concerning the purchasing decisions about US pork, consumer attitudes toward US beef are more influential than the interest of households in country-of-origin information, although the impact on their purchasing decisions about US vegetables are at the same level. This indicates that it is easy for households to suspect the relationship between safety of pork and BSE because pork is a meat similar to beef, which is related to BSE. 


\section{Conclusion}

In this paper, we use a probit model based on a questionnaire survey to analyze what types of households tend to avoid US agricultural products. We show that: (1) households willing to buy US beef after the BSE outbreak are less likely to avoid US pork and vegetables; (2) households in Tokyo, which consume less beef, have a tendency not to reduce their demand for US pork and vegetables; (3) households that care about country-of-origin information tend to avoid US agricultural products; and (4) households without children are apt to avoid US pork compared with households with children.

Additionally, we ascertain what characteristics of households have a significant impact on the purchasing decisions of households of US agricultural products, and find a difference in the impact on demand for US pork and vegetables. As a result, the willingness of consumers to buy US beef and the interest of households in country-of-origin information have more significant impacts on the decisions of households to purchase US agricultural products. We also show that the attitudes of consumers toward US beef have a greater influence on the decisions of households to purchase US pork than they do on purchases of US vegetables because households may perceive a higher probability of a health hazard from pork, which is regarded as being almost the same product as beef.

We conclude the paper with the following outstanding issues. First, it is difficult to evaluate such a dynamic effect with one questionnaire survey, such as the one conducted in this study. If we would like to collect these data, it would have to be panel data on the same sample individuals. Second, we selected the subjects from a telephone directory. Sampling from a telephone directory may cause sampling bias because many households refuse to list their phone numbers in a telephone directory. However, we are unable to discuss how the bias affects our results at this time. These two issues are to be considered in further research.

\section{References}

Barrena, R., \& Sánchez, M. (2010). Differences in Consumer Abstraction Levels as a Function of Risk Perception. Journal of Agricultural Economics, $61(1), \quad 34-59$. http://dx.doi.org/10.1111/j.1477-9552.2009.00224.x

Beverland, M., \& Lindgreen, A. (2002). Using Country of Origin in Strategy: The Importance of Context and Strategic Action. Brand Management, 10(2), 147-167. http://dx.doi.org/10.1057/palgrave.bm.2540112

Dosman, D. M., Adamowicz, W. L., \& Hrudey, S. E. (2002). Socioeconomic Determinants of Health- and Food Safety-Related Risk Perceptions. Risk Analysis, 21(2), 307-318. http://dx.doi.org/10.1111/0272-4332.212113

Gould, G. W., \& Villarreal, H. J. (2002). Adult Equivalence Scale and Food Expenditures: An Application to Mexican Beef and Pork Purchases. Applied Economics, 34(9), 1075-1088. http://dx.doi.org/10.1080/00036840110074141

Henson, S., \& Northen, J. (2000). Consumer Assessment of the Safety of Beef at the Point of Purchase: A Pan-European Study. Journal of Agricultural Economics, 51(1), 90-105. http://dx.doi.org/10.1111/j.1477-9552.2000.tb01211.x

Hong, S. T., \& Wher, R. S. Jr. (1990). Determinants of Product Evaluation: Effects of the Time Interval between Knowledge of a Product's Country of Origin and Information about its Specific Attributes. The Journal of Consumer Research, 17(3), 277-288. http://dx.doi.org/10.1086/208557

Hong, S. T., \& Wyer, R. S. Jr. (1989). Effects of Country-of-Origin and Product Attribute Information on Product Evaluation: An Information Processing Perspective. The Journal of Consumer Research, 16(2), 175-187. http://dx.doi.org/10.1086/209206

Ishida, T., Ishikawa, N., \& Fukushige, M. (2010). Impact of BSE and Bird Flu on Consumers' Meat Demand in Japan. Applied Economics, 56(1), 49-56. http://dx.doi.org/10.1080/00036840701564392

Janda, S., \& Rao, C. P. (1997). The Effect of Country-of-Origin Related Stereotypes and Personal Beliefs on Product Evaluation. Psychology and Marketing, 14(7), 689-702. http://dx.doi.org/10.1002/(SICI)1520-6793(199710)14:7<689::AID-MAR4>3.0.CO;2-C

Lin, C. T. J. (1995). Demographic \& Socioeconomic Influences on the Importance of Food Safety in Food Shopping. Agricultural and Resource Economics Review, 24(2), 190-198.

Maheswaran, D. (1994). Country of Origin as a Stereotype: Effects of Consumer Expertise and Attribute Strength on Product Evaluations. The Journal of Consumer Research, 21(2), 354-65. http://dx.doi.org/10.1086/209403 
Marsh, T. L., Schroeder, T. C., \& Mintert, J. (2004). Impact of Meat Product Recalls on Consumer Demand in the USA. Applied Economics, 36(9), 897-909. http://dx.doi.org/10.1080/0003684042000233113

Pennings, J. M. E., Wansink, B., \& Meulenberg, M. T. G. (2002). A Note on Modeling Consumer Reactions to a Crisis: The Case of the Mad Cow Disease. International Journal of Research in Marketing, 19(1), 91-100. http://dx.doi.org/10.1016/S0167-8116(02)00050-2

Peterson, H. H., \& Chen, Y. -J. (2005). The Impact of BSE on Japanese Retail Meat Demand. Agribusiness, 21, 313-327. http://dx.doi.org/10.1002/agr.20050

Renner, B., Schüz, B., \& Sniehotta, F. F. (2008). Preventive Health Behavior and Adaptive Accuracy of Risk Perceptions. Risk Analysis, 28(3), 741-748. http://dx.doi.org/10.1111/j.1539-6924.2008.01047.x

Saghaian, S. H., Maynard, L.J., \& Reed, M. R. (2007). The Effects of E. coli 0157:H7, FMD and BSE on Japanese Retail Beef Prices: A Historical Decomposition. Agribusiness, 23(1), 131-147. http://dx.doi.org/10.1002/agr.20106

Tonsor, G. T., Schroeder, T. C., \& Pennings, J. M. E. (2009). Factors Impacting Food Safety Risk Perceptions. Journal of Agricultural Economics, 60(3), 625-644. http://dx.doi.org/10.1111/j.1477-9552.2009.00209.x

van der Lans, I. A., van Ittersum, K. , De Cicco, A., \& Loseby, M. (2001). The Role of the Region of Origin and EU Certificates of Origin in Consumer Evaluation of Food Products. Food Policy, 28(4), 451-477. http://dx.doi.org/10.1093/erae/28.4.451

van Ittersum, K., Candel, M. J. J. M., \& Meulenberg, M. T. G. (2003). The Influence of the Image of a Product's Region of Origin on Product Evaluation. Journal of Business Research, 56(3), 215-226. http://dx.doi.org/10.1016/S0148-2963(01)00223-5

Verbeke, W., \& Ward, R. W. (2001). A Fresh Meat Almost Ideal Demand System Incorporating Negative TV Press and Advertising Impact. Agricultural Economics, 25(2-3), 359-374. http://dx.doi.org/10.1111/j.1574-0862.2001.tb00215.x

Verbeke, W., Ward, R.W., \& Viaene, J. (2000). Probit Analysis of Fresh Meat Consumption in Belgium: Exploring BSE and Television Communication Impact. Agribusiness, 16(2), 215-234. http://dx.doi.org/10.1002/(SICI)1520-6297(200021)16:2<215::AID-AGR6>3.0.CO;2-S

Viscusi, W. K. (1990). Do Smokers Underestimate Risks? Journal of Political Economy, 98(6), 1253-1269. http://dx.doi.org/10.1086/261733

Zepeda, L., Douthitt, R., \& You, S. Y. (2003). Consumer Risk Perceptions toward Agricultural Biotechnology, Self-protection, and Food Demand: The Case of Milk in the United States. Risk Analysis, 23(5), 973-984. http://dx.doi.org/10.1111/1539-6924.00374

\section{Data}

Ministry of Internal Affairs and Communications. (2002-2006). Family Income and Expenditure Survey.

Ministry of Internal Affairs and Communications. (2005). Census.

Ministry of Internal Affairs and Communications. (2004). National Survey of Family Income and Expenditure. 
Table 1. Summary statistics of the questionnaire results

\begin{tabular}{|c|c|c|c|c|c|c|c|}
\hline \multirow{4}{*}{$\begin{array}{c}\text { Area } \\
\\
\\
\text { Tokyo } \\
\text { (fewer prefer } \\
\text { beef) }\end{array}$} & \multirow{3}{*}{$\begin{array}{l}\text { Consumers' willingness to buy US beef } \\
\text { With or without blanket testing } \\
\text { Willing to buy without blanket testing } \\
\text { Willing to buy if blanket testing were } \\
\text { introduced }\end{array}$} & \multicolumn{2}{|c|}{ Total } & \multicolumn{2}{|c|}{$\begin{array}{l}\text { Households that do } \\
\text { not refrain from } \\
\text { buying US pork* }\end{array}$} & \multicolumn{2}{|c|}{$\begin{array}{l}\text { Households that } \\
\text { do not refrain } \\
\text { from buying US } \\
\text { vegetables** }\end{array}$} \\
\hline & & 97 & $(50 \%)$ & 88 & $(91 \%)$ & 92 & $(95 \%)$ \\
\hline & & 48 & $(25 \%)$ & 30 & $(63 \%)$ & 41 & $(85 \%)$ \\
\hline & $\begin{array}{l}\text { Not willing to buy even if blanket testing } \\
\text { were introduced }\end{array}$ & 48 & $(25 \%)$ & 16 & $(33 \%)$ & 33 & $(69 \%)$ \\
\hline & Total & 193 & $(100 \%)$ & 134 & $(69 \%)$ & 166 & $(86 \%)$ \\
\hline \multirow{4}{*}{$\begin{array}{c}\text { Osaka } \\
\text { (more prefer } \\
\text { beef) }\end{array}$} & Willing to buy without blanket testing & 84 & $(44 \%)$ & 71 & $(85 \%)$ & 79 & $(94 \%)$ \\
\hline & $\begin{array}{l}\text { Willing to buy if blanket testing were } \\
\text { introduced }\end{array}$ & 69 & $(36 \%)$ & 30 & $(43 \%)$ & 46 & $(67 \%)$ \\
\hline & $\begin{array}{l}\text { Not willing to buy even if blanket testing } \\
\text { were introduced }\end{array}$ & 37 & $(19 \%)$ & 14 & $(38 \%)$ & 24 & $(65 \%)$ \\
\hline & Total & 190 & $(100 \%)$ & 115 & $(61 \%)$ & 149 & $(78 \%)$ \\
\hline \multirow{4}{*}{ Total } & Willing to buy without blanket testing & 181 & $(47 \%)$ & 159 & $(88 \%)$ & 171 & $(94 \%)$ \\
\hline & $\begin{array}{l}\text { Willing to buy if blanket testing were } \\
\text { introduced }\end{array}$ & 117 & $(31 \%)$ & 60 & $(51 \%)$ & 87 & $(74 \%)$ \\
\hline & $\begin{array}{l}\text { Not willing to buy even if blanket testing } \\
\text { were introduced }\end{array}$ & 85 & $(22 \%)$ & 30 & $(35 \%)$ & 57 & $(67 \%)$ \\
\hline & Total & 383 & $(100 \%)$ & 249 & $(65 \%)$ & 315 & $(82 \%)$ \\
\hline
\end{tabular}

* The figures in parentheses indicate the proportion of households that do not avoid US pork according to their willingness to buy US beef with or without blanket testing.

** The figures in parentheses indicate the proportion of households that do not avoid US vegetables according to their willingness to buy US beef with or without blanket testing.

Table 2. Definitions and means of explanatory variables

\begin{tabular}{|c|c|c|c|c|}
\hline Description & Dummy variables & Tokyo & Osaka & Total \\
\hline \multicolumn{5}{|l|}{ Consumers' willingness to buy US beef } \\
\hline Willing to buy US beef without blanket testing & beef $_{\mathrm{A}}=1 \&$ beef $_{\mathrm{B}}=0$ & 0.50 & 0.44 & 0.47 \\
\hline Willing to buy US beef if blanket testing were introduced & beef $_{A}=0 \&$ beef $_{B}=1$ & 0.25 & 0.36 & 0.31 \\
\hline Not willing to buy even if blanket testing were introduced & beef $_{\mathrm{A}}=0 \&$ beef $_{\mathrm{B}}=0$ & 0.25 & 0.19 & 0.22 \\
\hline \multicolumn{5}{|l|}{ Level of awareness toward country-of-origin information } \\
\hline Pay attention to country-of-origin information for pork & country $_{\text {pork }}=1$ & 0.17 & 0.16 & 0.17 \\
\hline Pay no attention to country-of-origin information for pork & country $_{\text {pork }}=0$ & 0.83 & 0.84 & 0.83 \\
\hline Pay attention to country-of-origin information for vegetables & country $_{\text {vegetable }}=1$ & 0.23 & 0.22 & 0.23 \\
\hline Pay no attention to country-of-origin information for vegetables & country $_{\text {vegetable }}=0$ & 0.77 & 0.78 & 0.77 \\
\hline \multicolumn{5}{|l|}{ Family structure } \\
\hline Households with one or more members aged under 20 years & chi $=1$ & 0.24 & 0.30 & 0.27 \\
\hline Households without one or more members aged under 20 years & chi $=0$ & 0.76 & 0.70 & 0.73 \\
\hline Households with one or more members aged over 60 years & old $=1$ & 0.64 & 0.58 & 0.60 \\
\hline Households without one or more members aged over 60 years & old $=0$ & 0.36 & 0.42 & 0.40 \\
\hline \multicolumn{5}{|l|}{ Household income } \\
\hline Income (million yen) & inc(continuous) & 7.22 & 6.63 & 6.93 \\
\hline Sample size & & 193 & 190 & 383 \\
\hline
\end{tabular}


Table 3. Empirical results

\begin{tabular}{|c|c|c|c|c|c|c|c|c|c|c|c|}
\hline \multirow[b]{3}{*}{ variables } & \multicolumn{6}{|c|}{ Pork } & \multicolumn{5}{|c|}{ Vegetable } \\
\hline & \multicolumn{2}{|c|}{ Full model } & \multicolumn{4}{|c|}{ Minimum AIC model } & \multicolumn{2}{|c|}{ Full model } & \multicolumn{3}{|c|}{ Minimum AIC model } \\
\hline & Coefficient & t-statics & & Coefficient & t-statics & & Coefficient & t-statics & Coefficient & t-statics & \\
\hline constant term & -0.62 & $(-2.10)$ & * & -1.59 & $(-8.95)$ & $* *$ & 0.36 & $(1.09)$ & -0.40 & $(-3.02)$ & ** \\
\hline tokyo & 0.44 & $(2.73)$ & ** & 0.37 & $(2.41)$ & $*$ & 0.49 & $(2.43)$ & 0.36 & ( 1.84$)$ & \\
\hline beef $_{\mathrm{A}}$ & 1.65 & $(8.42)$ & ** & 1.58 & ( 8.08$)$ & ** & 1.49 & $(5.80)^{* *}$ & 1.16 & ( 5.17$)$ & ** \\
\hline beef $_{\mathrm{B}}$ & 0.50 & $(2.54)$ & * & 0.46 & $(2.33)$ & $*$ & 0.41 & $(1.93)$ & & & \\
\hline country $_{\text {pork }}$ & -0.45 & $(-2.68)$ & & -0.29 & $(-3.01)$ & ** & - & & - & & \\
\hline country $_{\text {vegetable }}$ & - & & & 一 & & & -0.76 & $(-4.58)^{* *}$ & -0.51 & $(-4.76)$ & ** \\
\hline chi & 0.37 & $(2.03)$ & * & 0.37 & $(2.21)$ & * & -0.35 & $(-0.17)$ & & & \\
\hline old & -0.39 & $(-0.23)$ & & & & & -0.05 & $(-0.27)$ & & & \\
\hline $\log ($ inc) & -0.02 & $(-0.18)$ & & & & & -0.05 & $(-0.35)$ & & & \\
\hline $\log -\mathrm{L}$ & -195 & & & -194 & & & -148 & & -148 & & \\
\hline AIC & 407. & & & 401. & & & 313. & & 304.2 & & \\
\hline Hit or Lose Ratio & 0.67 & & & 0.75 & & & 0.82 & & 0.82 & & \\
\hline $\mathrm{n}$ & 383 & & & 383 & & & 383 & & 383 & & \\
\hline
\end{tabular}

Note: $* *$ and $*$ mean significant at the $1 \%$ and $5 \%$ levels, respectively.

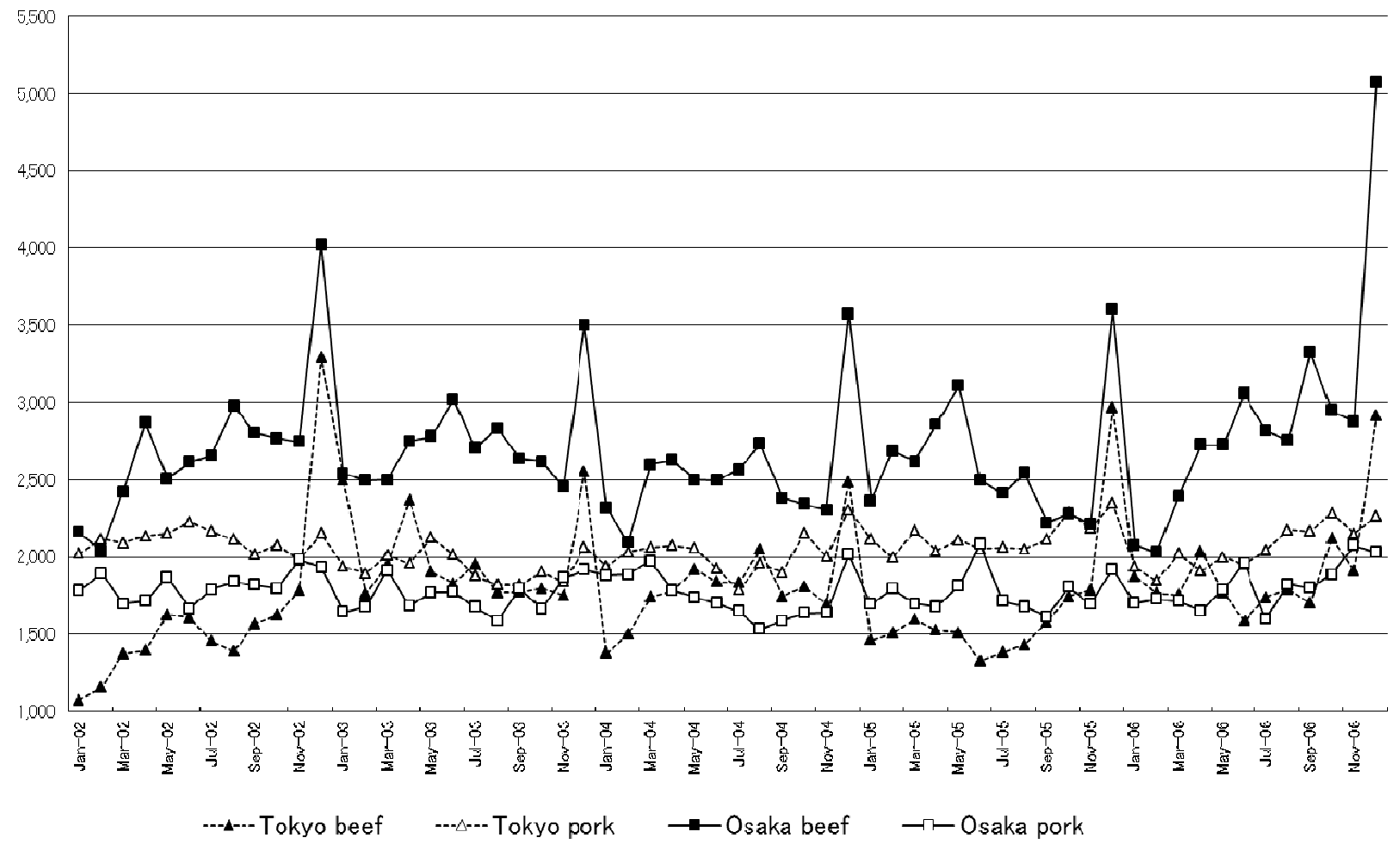

Figure 1. Shift of expenditure on beef and pork 


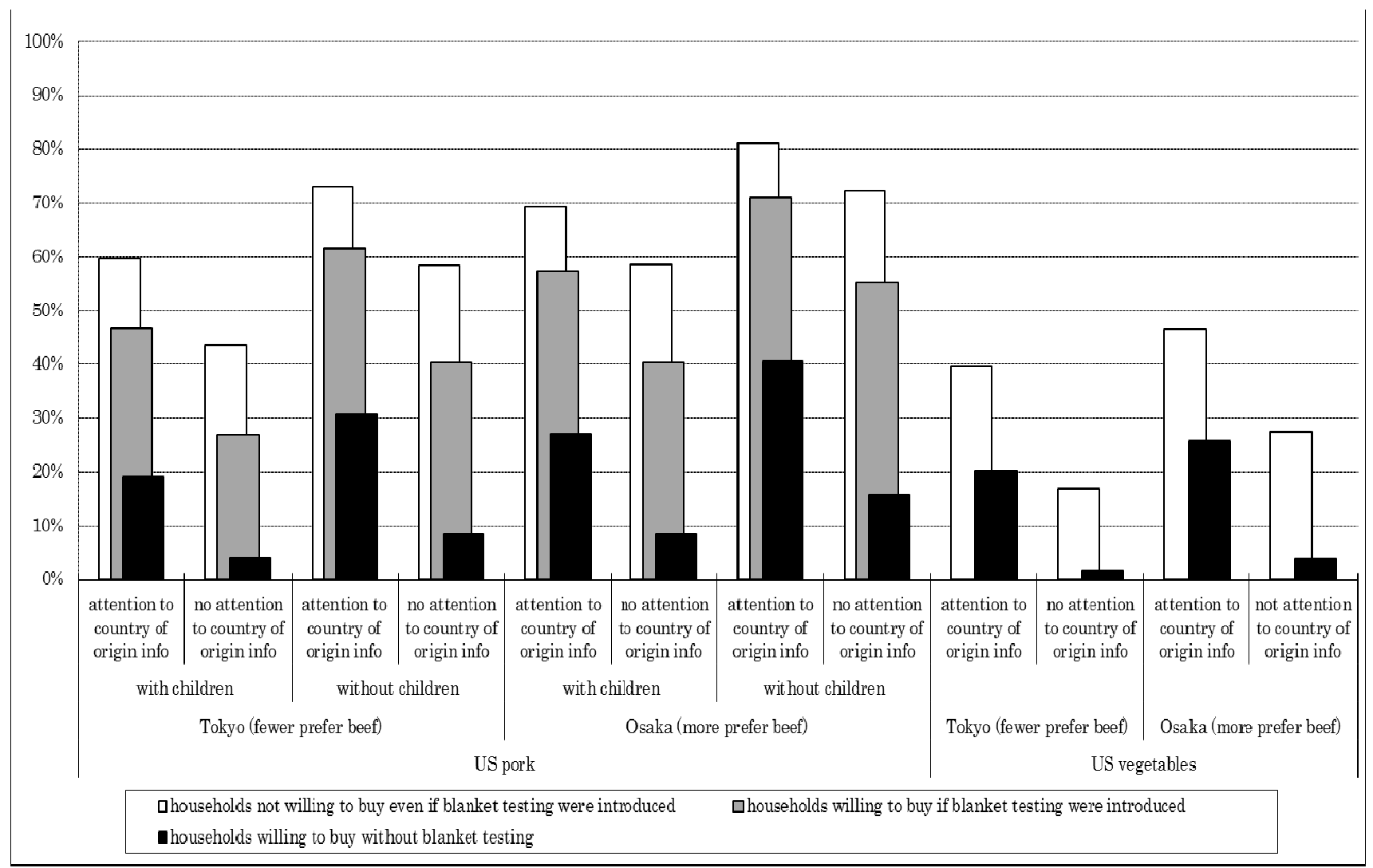

Figure 2. Estimated probabilities of refraining from buying US products for each type of household 